\title{
O PRINCÍPIO DA FUNDAMENTAÇÃO DAS DECISÕES JUDICIAIS E O SOLIPSISMO NAS DECISÕES DO SUPREMO TRIBUNAL FEDERAL
}

\author{
THE PRINCIPLE OF SUBSTANTIATION OF JUDICIAL DECISIONS AND THE \\ SOLIPSISM IN THE DECISIONS OF THE BRAZILIAN SUPREME COURT (STF)
}

\author{
Laura Campolina Monti ${ }^{1}$ \\ Thaís Campos Maria ${ }^{2}$
}

\section{RESUMO}

Partindo da análise da evolução do principio da fundamentação das decisões judiciais e de sua interação com as demais garantias constitucionais do processo, tais como o contraditório e a ampla defesa, o estudo busca traçar um panorama da relevância desse principio, bem como do alcance de eventuais violações ao mesmo. Nessa linha, o trabalho se debruça especificamente sobre alguns julgados do Supremo Tribunal Federal a fim de verificar como a corte encarregada de zelar pelo texto constitucional vem fundamentando suas decisões e justificando uma interpretação reducionista do principio da fundamentação, o que favorece julgados de caráter cada vez mais solipsista.

Palavras-chave: Princípio da fundamentação das decisões, Motivação das decisões judiciais, Solipsismo das decisões judiciais, Supremo tribunal federal

\begin{abstract}
This dissertation is the summary of a research about the evolution of the principle of substantiation of judicial decision and the interactions between that and other constitutional guarantees of process. The study intents to draw a scenery that reveals the relevance of such principle as well as the reach of eventual violations of it. The research focus specifically on some decisions of the Brazilian Supreme Court in order to verify how is the court responsible for defending the constitutional text substantiating its decisions and justifying a reductionist interpretation of such principle, what favors decisions with a solipsist trace.
\end{abstract}

Keywords: The principle of substantiation, Motivation of judicial decisions, Solipsism of judicial decisions, Brazilian supreme court

\footnotetext{
1 Mestranda em Direito Público pela Fundação Mineira de Educação e Cultura- Universidade FUMEC, Minas Gerais, (Brasil). E-mail: laura.campolinamonti@ hotmail.com

2 Mestranda em Direito pela Fundação Mineira de Educação e Cultura - Universidade FUMEC, Minas Gerais, (Brasil). Servidora Pública Federal exercendo a função de Coordenadora de Pesquisa no Instituto Federal Minas Gerais, (Brasil). E-mail: tahcampos@ hotmail.com
} 


\section{INTRODUÇÃO}

A fundamentação, não restrita no âmbito judicial a mera motivação do julgador, nos termos do art.93, IX, da Constituição Federal é requisito de validade dos pronunciamentos decisórios e, em se tratando de sentença, um dos elementos formais indispensáveis do ato. ${ }^{3}$ Tal é a relevância da fundamentação nas decisões judiciais que atualmente já é pacifico o entendimento quanto à existência e validade, no ordenamento jurídico brasileiro, do chamado principio da fundamentação (ou da motivação) das decisões judiciais ${ }^{4}$.

O referido princípio revela-se ainda mais relevante na medida em que se articula com outros princípios e garantias de caráter constitucional, tais como o contraditório e a ampla defesa, para a consecução do devido processual legal e a manutenção da vigência do próprio texto constitucional, uma vez que a fundamentação das decisões é garantia contra possíveis excessos do Estado-juiz, viabilizando um maior controle do processo e permitindo, quando for o caso, sua impugnação. Nesse sentido, Luigi Ferrajoli (2002) aponta que o princípio da fundamentação das decisões judiciais "exprime e ao mesmo tempo garante a natureza cognitiva em vez da natureza potestativa do juízo, vinculando-o, em direito, à estrita legalidade, e, de fato, à prova das hipóteses acusatórias."

A despeito da evidente importância do principio em questão e de seu viés eminentemente prático, o que se observa não raro nas decisões do Supremo Tribunal Federal (STF), órgão de cúpula do Poder Judiciário brasileiro ao qual a Constituição de 1988 conferiu a função precípua de guardião do texto constitucional, são decisões extremamente sucintas que, valendo-se do entendimento de que o magistrado não está obrigado a responder a todas as alegações trazidas pelas partes, tampouco a se pronunciar sobre todos os fundamentos alegados, flexibilizam o principio da fundamentação.

\footnotetext{
${ }^{3}$ Lei nº5.869, de 11 de janeiro de 1973, arts. 165 e 458, II; Código de Processo Civil, arts. 11 e 489; Código de Processo Penal, arts. 381, III e IV; Lei nº 9.099, de 26 de setembro de 1995, art. 38; Consolidação das Leis do Trabalho, art. 832; Código de Processo Penal Militar, art. 438, b, c e d.

${ }^{4}$ A opção pelo uso do termo princípio da fundamentação e não princípio da motivação são se fez neste trabalho de forma aleatória. A diferenciação entre as nomenclaturas, no entanto, não é alvo deste artigo, para uma abordagem do tema conferir CATTONI, 2013, p.138-178.
} 
A relativização de um alicerce do devido processo legal, transferindo sua aplicação ao arbítrio do magistrado, merece atenção não somente em face dos processos de grande repercussão midiática que atualmente tramitam no Supremo Tribunal Federal, mas diante da potencial ofensa ao texto constitucional perpetrada, neste contexto, pelo órgão que deveria por ele zelar.

Em face de tal problemática, o presente estudo lança mão da dogmática jurídica, bem como de fontes relevantes de doutrina, a fim de proceder a uma breve análise da jurisprudência do STF e avaliar seu posicionamento com relação ao principio da fundamentação das decisões judiciais, não pretendendo, no entanto, esgotar a questão, mas antes disso fomentar a reflexão.

\section{O PRINCÍPIO DA FUNDAMENTAÇÃO DAS DECISÕES}

O Estado Democrático de Direito encontra suas bases jurídico constitucional em um conjunto de normas, compostos por princípios e regras, explícitos no texto constitucional brasileiro (BRÊTAS, 2004, p.61). Nessa linha, tendo em vista a discussão ora proposta, destaca-se o princípio da fundamentação das decisões proferidas pelos órgãos jurisdicionais, previsto no artigo 93, incisos IX e X da Constituição Federal de 1988, por meio de uma breve e minuciosa apresentação de pontos pertinentes e de grande relevância sobre o tema.

A “função jurisdicional deve estar disciplinada por uma rigorosa obediência aos princípios constitucionais, notadamente no que diz respeito à fundamentação" (GHEDINI NETO, 2015, p. 266).

Inicialmente, cumpre dizer que não é objeto desta pesquisa uma ampla e detalhada análise do direito comparado no que diz respeito ao estudo e desenvolvimento deste princípio. Entretanto, convém mencionar que Ronaldo Brêtas (2004) escreve que o direito brasileiro assemelha-se ao direito italiano por também trazer o princípio da fundamentação das decisões na legislação constitucional vigente. Apenas a título exemplificativo o mesmo autor cita o artigo 111 da constituição italiana e o artigo 132 do Código Civil italiano que recomendam, respectivamente: "todos os provimentos jurisdicionais devem ser motivados" e "a concisa exposição do desenvolvimento do processo e dos motivos de fato e de direito da decisão ${ }^{5}$. É possível fazer referencia ainda ao artigo 455 do Código de Processo Civil francês "o julgamento deve ser 
motivado"6 e aos códigos processuais civis alemão e português, demonstrando a notória presença do princípio da fundamentação das decisões em ordenamentos jurídicos diversos do

brasileiro, evidenciando o dever que os órgãos jurisdicionais possuem de motivar uma decisão ao proferi-la.

Conforme dito alhures, o princípio da fundamentação das decisões constitui um "mandamento constitucional, CF, art. 93, IX"7, não obstante, além de presente em nível constitucional, o dito princípio encontrava-se também previsto em nível infraconstitucional nos artigos 165 e 458 do Código de Processo Civil de 1973, que incluem entre os requisitos estruturais da sentença os fundamentos, que abrangem a obrigatória análise das questões de fato e de direito discutidas pelas partes no processo, e o dispositivo, no qual o órgão jurisdicional resolverá tais questões (BRÊTAS, 2004, p.127).

Apesar de não mais em vigor, o CPC de 1973 contribui para o estudo do principio em questão, principalmente do ponto de vista histórico evolutivo da legislação. Extrai-se, da leitura do antigo artigo 458 do Código de Processo Civil de 1973 que são requisitos necessários à formação das sentenças proferidas pelo órgão jurisdicional o relatório, a fundamentação ou motivação, e a conclusão ou dispositivo. Sendo que por fundamentação entende-se:

(...) elemento da decisão em que o julgador vai analisar as questões e justificar racionalmente, através de uma exposição das razões de fato e de direito, o motivo do acolhimento ou não da pretensão. A fundamentação não é um simples elemento constitutivo dos pronunciamentos jurisdicionais decisórios, mas se caracteriza também por ser uma garantia processual de constituição e manutenção de um Estado Democrático de Direito. (GHEDINI NETO, 2015, p. 265).

As referidas disposições correspondem, na realidade, a uma tradição do direito brasileiro, sendo significativo consignar que o primeiro estatuto de direito processual civil brasileiro, o Regulamento $\mathrm{n}^{\circ} 737$, de 25 de novembro de 1850 , já trazia regras sobre a matéria em seu art.232.

\footnotetext{
${ }^{5}$ BRÊTAS, Ronaldo de Carvalho Dias (2004, p.126).

${ }^{6}$ BRÊTAS, Ronaldo de Carvalho Dias (2004, p.126).

${ }^{7}$ Expressão utilizada por NOGUEIRA, José Maurício. “Aspectos sobre o controle das decisões judiciais” (2008, p.241).
} 
A despeito da presença de dispositivos sobre o tema no ordenamento pátrio há mais de cem anos, é certo que a Constituição de 1988 avançou alçando o principio à eminência de norma fundamental do Estatuto da Magistratura, pelo que cabe ao julgador no ato de decidir apresentar argumentos objetivos e não subjetivos para embasarem sua decisão e assim, fundamentá-la, garantindo a legitimidade do seu ato e a segurança dos jurisdicionados:

(...) perante a nova ordem constitucional, às garantias do processo e ao paradigma do Estado Democrático de Direito, o provimento jurisdicional, sob o ponto de vista interpretativo, não mais pode ser abordado como ato solitário do julgador (LEAL, A. 2002, p. 20).

Com o intuito de zelar por um processo justo e controlando eventuais abusos processuais que possam ocorrer ao longo do mesmo, o princípio da fundamentação das decisões contribui para a afirmação do Estado Democrático de Direito, na medida em que exige do julgador fundamentar sua decisão, primando pela democraticidade. Nessa linha, o principio da fundamentação das decisões traduz um postulado político do Estado Democrático de Direito. Como observa José Carlos Barbosa Moreira (1988), tal postulado, à luz da doutrina alemã, representa o "Estado que se justifica". Nas palavras do referido autor: "É preciso que o pronunciamento da Justiça, destinado a assegurar a inteireza da ordem jurídica, realmente se funde na lei, e é preciso que esse fundamento se manifeste, para que possa saber se o império da lei foi na verdade assegurado."

Entende-se que a democracia é "um processo dinâmico permitindo que os cidadãos participem de forma crítica no processo e em condições de igualdade" (GHEDINI NETO, 2015, P. 266). Ou seja, é direito das partes a participação durante o caminhar do processo e consequentemente na formação da decisão, cabendo ao princípio do contraditório não se resumir unicamente no dizer e contradizer, mas em garantir e oportunizar de maneira ampla a "dialogicidade necessária entre os interlocutores (partes) que se postam em defesa ou disputa de direitos alegados" (LEAL, R., 2014, p.99), evidenciada, portanto, a importância da fundamentação na efetivação das garantias processuais como um todo como se verá mais adiante. 


\subsection{O PRINCÍPIO DA FUNDAMENTAÇÃO NO NOVO CÓDIGO DE PROCESSO CIVIL (CPC)}

É inconteste a obrigatoriedade que os magistrados possuem de fundamentar as decisões ao prolatá-las. Sendo essa norma constitucional importante para a construção da democraticidade. Somente a partir das razões e motivos utilizados pelos julgadores de forma clara e precisa é possível uma defesa na esfera recursal. Entretanto, o artigo 93 da Constituição apenas determinou o dever da fundamentação das decisões, não trazendo uma regulamentação de como se deve constituir uma decisão motivada pelo órgão jurisdicional.

Nem mesmos as normas infraconstitucionais do Código de Processo Civil de 1973 se preocuparam em definir de forma detalhada os critérios, mencionando apenas em seu artigo 458, inciso II que cabe ao juiz analisar as questões de fato e direito, o que acaba dando ao magistrado uma maior autonomia e liberdade ao proferir as sentenças.

"O ato escritural do juiz deve poder se desgarrar de seu prolator (ausência de referencia à "autoridade" e a critérios pessoais de "justiça") e se oferecer a crítica" (LEAL, A. 2008, p. 151). Entretanto, tal posicionamento esbarra em lacunas, em razão da carência de normatividade que estabeleça requisitos balizadores para a atuação dos magistrados no tocante à fundamentação de suas decisões, abrindo espaço para uma maior liberdade desses quanto ao ato de julgar.

Neste sentido, questões acerca dos limites da liberdade de convencimento do juiz recebem novas dimensões teóricas, em vista do entrelaçamento do paradigma do Estado Democrático de Direito e de suas implicações principiológicas (LEAL, A. 2002, p. 20). A aprovação do novo Projeto de Lei do Senado - PLS 166/2010 que institui o Novo Código de Processo Civil Brasileiro trouxe alterações que interferem diretamente no assunto em discussão, abarcando posicionamentos favoráveis e contrários.

O art. 11 do PLS n 166/2010, reproduziu o dispositivo legal do art. 93, IX, da Constituição da República, reafirmando a necessidade da fundamentação da decisão sob pena de nulidade. Além de mencionar o que o antigo Código Processual Civil já estabelecia: que a fundamentação é um requisito essencial da sentença, consistindo na análise das questões de fato e de direito (OLIVEIRA, 2016, p. 110). A atual legislação processualista vigente trouxe em seu bojo o artigo $489, \S 1^{8}$, que prevê como as decisões judiciais não devem ser 
fundamentadas. Incorrendo o julgador nas situações elencadas pelo mencionado artigo a decisão judicial será tida como não fundamentada.

A inovação legislativa processual altera, portanto a atuação dos magistrados, elencando critérios para se afirmar quando uma determinada decisão não estará motivada, implicando diretamente no princípio da fundamentação das decisões, possibilitando na reforma e até mesmo na anulação da sentença.

Contribuindo para este entendimento e reforçando a importância do dito princípio, Ronaldo Brêtas (2004) elenca algumas razões lógicas e relevantes para reforçar a necessidade de observância do princípio da fundamentação das decisões. Para o mencionado autor, a fundamentação proporciona, em face de um Estado Democrático de Direito, um controle de constitucionalidade da função jurisdicional, o que permite identificar se o pronunciamento esta vinculado ao ordenamento jurídico vigente; contribui para uma maior observância das ideologias e subjetividades do julgador quanto a seu ato decisório; favorece a verificação da racionalidade da decisão e por fim, oferece a possibilidade de estruturação dos eventuais recursos interpostos, zelando pelos princípios da recorribilidade e do duplo grau de jurisdição (BRÊTAS, 2004, p.132).

\footnotetext{
${ }^{8}$ Art. 489. São elementos essenciais da sentença:

I - o relatório, que conterá os nomes das partes, a identificação do caso, com a suma do pedido e da contestação, e o registro das principais ocorrências havidas no andamento do processo;

II - os fundamentos, em que o juiz analisará as questões de fato e de direito;

III - o dispositivo, em que o juiz resolverá as questões principais que as partes lhe submeterem.

$\S 1^{\circ}$ Não se considera fundamentada qualquer decisão judicial, seja ela interlocutória, sentença ou acórdão, que:

I - se limitar à indicação, à reprodução ou à paráfrase de ato normativo, sem explicar sua relação com a causa ou a questão decidida;

II - empregar conceitos jurídicos indeterminados, sem explicar o motivo concreto de sua incidência no caso;

III - invocar motivos que se prestariam a justificar qualquer outra decisão;

IV - não enfrentar todos os argumentos deduzidos no processo capazes de, em tese, infirmar a conclusão adotada pelo julgador;

V - se limitar a invocar precedente ou enunciado de súmula, sem identificar seus fundamentos determinantes nem demonstrar que o caso sob julgamento se ajusta àqueles fundamentos;

VI - deixar de seguir enunciado de súmula, jurisprudência ou precedente invocado pela parte, sem demonstrar a existência de distinção no caso em julgamento ou a superação do entendimento.
} 
O referido dispositivo inserido no novo CPC é passível de críticas. Questiona-se o fato de se exigir que sejam rebatidos todos os argumentos levantados pelas partes na relação processual, o que acarretaria certa morosidade do processo, influindo diretamente na celeridade e eficiência processual. Ademais se coloca em pauta a questão da discricionariedade do magistrado, o que abre espaços no meio jurídico para questionamentos em relação à autonomia que o julgador possui para decidir sobre a valoração dos argumentos enfrentados. Neste viés muito contribuem as palavras de Marcelo Andrade Cattoni de Oliveira:

Primeiramente cabe considerar que o êxito do PLS $n^{\circ} 166 / 2010$ abre a possibilidade de se reduzir fundamentação à mera motivação, caso haja abertura a uma desarticulação das exigências do contraditório e da fundamentação. Ou seja, a fundamentação seria um ato que representaria o apontamento pelo juiz dos elementos que ele considerou mais relevante no caso e que fizeram com que ele tomasse tal decisão e não outra (OLIVEIRA, 2016, p. 110 grifos do autor).

Marcelo Catonni (OLIVIERA, 2016, p. 111) se posiciona dizendo que mesmo havendo o entendimento de que a necessidade de fundamentação permitiria um maior controle público da decisão, o ato de decidir é criação solipsista do magistrado, assim a redução da fundamentação à mera motivação teria implicações na legitimidade da decisão, uma vez que continuaria a reforçar a ideia de livre convencimento do julgador, sendo necessário, portanto, uma interpretação adequada do direito. A solução não reside em apenas uma reforma legislativa, "sem uma mudança de compreensão do Direito, do processo e da jurisdição, a nova legislação reproduzirá a mesma cultura jurídica” (OLIVEIRA, 2016, p.114).

\section{O PRINCÍPIO DA FUNDAMENTAÇÃO DAS DECISÕES E AS GARANTIAS CONSTITUCIONAIS DO PROCESSO}

O Poder Judiciário declara o Direito, devendo sempre, em um regime democrático e constitucional, defender a Carta Magna. No ordenamento jurídico brasileiro, que adota a ideia dos freios e contrapesos ${ }^{9}$, cabe ainda ao Poder Judiciário a incumbência de controlar os demais Poderes do Estado devendo utilizar para tanto parâmetros constitucionais. Nessa linha, resta patente a relevância do texto constitucional como elemento limitador e fundamental da atividade do Poder Judiciário. Tal relevância torna-se ainda mais marcada quando se passa a 
analisar especificamente o Supremo Tribunal Federal, órgão de cúpula do judiciário brasileiro ao qual a Constituição de 1988 atribuiu a função de zelar pelo texto constitucional.

Assim, a atuação do Supremo encontra-se vinculada ao texto constitucional, notadamente aos direitos fundamentais, resultando dessa vinculação não apenas o dever de guardar estrita obediência aos direitos fundamentais de caráter judicial, mas também o de assegurar a efetiva aplicação do direito, especialmente dos direitos fundamentais. Da referida vinculação resulta ainda a necessidade de se aferir a legitimidade das decisões judiciais, tendo em vista a correta aplicação desses direitos aos casos concretos (MENDES, 2004).

Há, portanto, um rol de direitos fundamentais diretamente associados à pratica judicial: são as chamadas garantias constitucionais do processo. Por garantias constitucionais do devido processo legal entende-se o conjunto de garantias que, por um lado, asseguram às partes o exercício de suas faculdades e poderes processuais e, por outro, são indispensáveis ao correto exercício da jurisdição. Tais garantias não servem apenas aos interesses das partes, como direitos públicos subjetivos destas, mas configuram, antes de mais nada, a salvaguarda do próprio processo, objetivamente considerado, como fator de legitimidade do exercício da jurisdição (CINTRA, GRINOVER, e DINAMARCO 2004). Indubitavelmente, insere-se neste elenco o principio da fundamentação das decisões.

Como visto acima, o principio da fundamentação das decisões se encontra previsto no art. 93, IX, da Constituição Federal e representa verdadeira garantia da jurisdição contra possíveis excessos do Estado-juiz. Nessa linha o STF já se pronunciou afirmando que:

A exigência de fundamentação das decisões judiciais, mais do que expressiva imposição consagrada e positivada pela nova ordem constitucional (art. $5^{\circ}$, IX), reflete uma poderosa garantia contra eventuais excessos do Estado-juiz, pois, ao torná-la elemento imprescindível e essencial dos atos sentenciais, quis o ordenamento jurídico erigi-la com fator de limitação dos poderes deferidos aos magistrados e Tribunais. ${ }^{10}$

\footnotetext{
${ }^{9}$ Sistema de checksand balances antecipado na teoria apresentada por Montesquieu em O Espírito das Leis.

${ }^{10}$ STF, HC 68.202, Rel. Min. Celso de Mello, DJ, 15.03.1991.
} 
Através da fundamentação, as decisões jurídicas tornam-se apoiadas e, portanto, legitimadas, por asserções verificáveis, pelo que a validade das sentenças condiciona-se à verdade, ainda que relativa, de seus argumentos. Por essa razão não é o Poder Judiciário um poder meramente potestativo, mas fundado no saber, ainda que só opinativo ou provável, mas exatamente por isso refutável e controlável tanto pelo imputado quanto pela sociedade (FERRAJOLI, 2002).

A decorrência lógica de tais fatos é que o principio da fundamentação não cons iste em norma estanque com aplicação isolada, mas operacionaliza-se em conjunto com diversos outros princípios e garantias constitucionais e processuais a fim de garantir não apenas o devido processo legal, mas também o próprio caráter democrático do Estado, uma vez que cerceia atuações despóticas e arbitrarias.

Pimenta Bueno, coadunando com as conclusões aqui apontadas, afirma que "[...] as decisões judiciais devem ser sempre motivadas, já para que se possa reconhecer se os fundamentos são ou não exatos, já também para que as partes interessadas possam considerar o como deverão instruir os respectivos recursos". Para além desse fundamento de garantia entre as partes, já se reconhece a função política da fundamentação das decisões, cujos destinatários não são apenas as partes e o juiz competente para julgar eventual recurso, mas quisquis de populo, com a finalidade de se aferir em concreto a imparcialidade do juiz e a justiça das decisões.

Se referindo à fundamentação das decisões, quando da análise dos dispositivos da Constituição Imperial que tratavam da responsabilidade legal e moral dos Juízes (arts. 154, 156, 157 e 159), Pimenta Bueno adverte para a circunstância de que os magistrados não podem ignorar que os olhos do povo estão sobre eles, e que seus equívocos ou abusos serão bem percebidos e expostos com energia à reprovação.

Nesse sentido, o tópico seguinte pretende com um olhar crítico verificar a ocorrência de equívocos na atuação do STF especificamente no tocante à aplicação do principio da fundamentação que, conforme detalhado acima, se propõe a garantir muito mais do que o mero direito das partes envolvidas. 


\section{O SOLIPSISMO NAS DECISÕES DO SUPREMO TRIBUNAL FEDERAL}

Neste ponto, a relevância do principio da fundamentação, bem como as potenciais implicações de sua violação já são evidentes. Nessa linha, destacamos no tópico anterior entendimento do Ministro Celso de Mello no sentido de ser o referido principio uma poderosa garantia contra eventuais excessos do Estado-juiz, erigida pelo ordenamento brasileiro a fator de limitação dos poderes deferidos aos magistrados e Tribunais.

Embora se pudesse alegar que o texto constitucional instituiu, em seu art. 93, esse e outros preceitos com o caráter de diretriz a ser seguida pelo Estatuto da Magistratura, o Supremo Tribunal Federal entendeu que se trata de norma de eficácia plena e aplicabilidade imediata, não dependendo para sua efetiva adoção de ulterior providencia legislativa ${ }^{11}$.

A despeito de o próprio STF reconhecer, conforme visto acima, o relevo do principio em questão, admitindo inclusive sua aplicação imediata quando da edição do texto constitucional de 1988, tem repetidamente decidido a referida corte não ser nula a sentença sucinta, desde que contenha o essencial em termos de fundamentação, tendo sido a questão abordada inclusive em sede de repercussão geral ${ }^{12}$. Apesar de se reconhecer o significativo volume de processos que chegam ao STF, o que inquestionavelmente compromete o andamento das ações - devendo se considerar nesse ponto a duração razoável do processo e o principio da celeridade - há que se atentar para o impacto de se condicionar a aplicação de uma garantia constitucional do processo ao subjetivismo do julgador.

Os riscos de ofensa a outras garantias processuais, bem como de cerceamento de direitos não é apenas teórico. O referido entendimento do STF tem dado guarida a falseamentos do principio da fundamentação em sentenças que se limitam a fazer referencia a pareceres do Ministério Público ou, até mesmo, a peças emanadas de uma das partes, como razão de decidir (MEDINA, 2006). Tal comportamento equivale à ausência de fundamentação, como bem considerou o Tribunal de Justiça do Estado do Rio Grande do Sul no seguinte aresto:

Não cabe ao juiz apena aderir explicitamente a alguma das teses esposadas, fazendo remissão às razões das partes, reproduzindo seus argumentos, ou adotando, como forma de decidir, trabalho jurídico no MP ou dos demandantes, que convalida simplesmente. ${ }^{13}$ 
Se no âmbito dos Tribunais inferiores já não se pode admitir tais manobras de desvio do imposto pelo texto constitucional, quanto mais nos limites do STF, ao qual incumbe a tarefa de guardião do texto constitucional. No entanto, na prática, verifica-se que não raro as decisões da corte se limitam à repetição de julgados anteriores, à remissão e reprodução integral de argumentos das partes e/ou à referência ao entendimento expresso no AI $n^{\circ}$ 791.292, de relatoria do Ministro Gilmar Mendes, onde se abordou a questão da fundamentação em sede de repercussão geral.

Em razão desses fatos, observa-se que não há no STF uma preocupação de se decidir de maneira especifica e criteriosa. Ao contrário, se decide genérica e indiscriminadamente, seguindo-se de maneira correlata a repercussão geral do tema $339^{14}$. Interpretam-se os casos semelhantes ou parecidos de maneira idêntica, não se levando em consideração as especificidades de cada um. $\mathrm{O}$ ato de interpretar que deveria ser cauteloso de forma a não ferir o direito do jurisdicionado, é impreciso, ocorrendo uma repetição das decisões já prolatadas nas esferas inferiores e na própria Corte.

$\mathrm{Na}$ busca de uma maior efetividade e celeridade do processo, desconsiderando a análise detalhada e minuciosa de cada caso concreto e desvalorizando os argumentos apresentados pelas partes, o Judiciário torna-se uma máquina de respostas jurídicas prontas para a sociedade, enfatizando a dita autoridade do órgão jurisdicional que perde sua legitimidade democrática ao prezar e priorizar o julgamento em bloco das matérias (OLIVEIRA, 2016, p. 112).

Não há uma preocupação por parte dos tribunais sejam de instância inferior ou superior em demonstrar as "razões que conduziram a tomada de decisão em um sentido e não outro. Reduzir-se-á o conteúdo decisório a breves enunciados (textos), como se fossem autoaplicáveis ou autoevidentes" (OLIVIERA, 2016, p. 113).

\footnotetext{
10 STF, ADIMC nº189/RJ, rel. Min. Celso de Mello, decisão do Tribunal Pleno em 18/04/1990, in A Constituição na Visão dos Tribunais, vol. 2, PP. 662/663.

${ }^{12}$ AI 791292 QO-RG, Rel. Min. GILMAR MENDES, julgado em 23/06/2010, repercussão geral.DJe-149 12/08/2010.

13 Acórdão in Revista Jurídica do Tribunal de Justiça do Estado do Rio Grande do Sul, 162/317, apud THEOTONIO NEGRÃO, Código de Processo Civil e legislação processual em vigor, p.467, nota $12 \mathrm{~b}$ ao art. 458 , II.
} 
Imperioso, neste sentido, ilustrar o dito alhures apresentando alguns julgados da Corte em estudo:

Ementa: AGRAVO REGIMENTAL EM RECURSO EXTRAORDINÁRIO COM AGRAVO. LEGISLAÇÃO ELEITORAL. CRIME ELEITOR AL. VIOLAÇÃO AO ART. 93, IX DA CF. INOCORRÊNCIA. VIOLAÇÃO AOS PRINCÍPIOS DO CONTRADITÓRIO, AMPLA DEFESA E DEVIDO PROCESSO LEGAL. OFENSA REFLEXA. 1. Ausência de omissão ao dever de fundamentar (AI 791.292 QO-RG, Rel. Min. Gilmar Mendes, Tema 339 da Repercussão Geral). 2. Não atende ao pressuposto de ofensa constitucional apta a ensejar o conhecimento do recurso extraordinário nesta Corte a alegação de ofensa a princípios constitucionais, quando sua verificação depender da análise de normas infraconstitucionais (Lei Complementar 67/90 e Código Eleitoral). 3. Agravo regimental a que se nega provimento.

(ARE 939246 AgR, Relator(a): Min. EDSON FACHIN, Primeira Turma, julgado em 01/03/2016, ACÓRDÃO ELETRÔNICO Dje-049 DIVULG 15-03-2016. PUBLIC 16-03-2016).

Cumpre dizer que a ementa se refere a decisão proferida pelo STF que negou, de maneira unânime, provimento ao agravo regimental interposto contra decisão em agravo denegatório de seguimento a recurso extraordinário, interposto no bojo de denúncia oferecida pela prática de crimes eleitorais previstos nos artigos 299 e 301 do Código Eleitoral.

No recurso extraordinário aponta-se ofensa aos arts. $5^{\circ}$, LIV e LV, e 93, IX, da CF. Sendo alegada a ausência de fundamentação da decisão recorrida, tendo em vista que as teses da defesa foram desconsideradas. A decisão do STF em face do agravo no extraordinário se baseou no entendimento pacífico ${ }^{15}$ do Pleno da desnecessidade de o órgão julgador verificar todos os argumentos das partes (autor e réu).

O Supremo Tribunal Federal ao negar outro provimento a agravo regimental discorre sobre o princípio da fundamentação das decisões. O posicionamento é no sentido de que não houve violação ao artigo 93, IX, da CF, já que o mencionado dispositivo legal não exige do órgão judicante a manifestação com relação a todos os argumentos apontados pela defesa,

\footnotetext{
${ }^{14}$ Repercussão geral que trata da fundamentação das decisões.

15 AI-QO-RG 791.292, de relatoria do Ministro Gilmar Mendes, DJe 13.8.2010, no qual o STF assentou a repercussão geral do tema 339, referente à negativa de prestação jurisdicional por ausência de fundamentação.
} 
mas, sim, que ele motive as razões do seu convencimento. Indo de encontro ao julgamento do AI n ${ }^{\circ}$ 791.292/PE-RG-QO, Tribunal Pleno, Relator o Ministro Gilmar Mendes, Dje de 13/8/10:

EMENTA Agravo regimental no recurso extraordinário com agravo. Direito Processual Civil. Artigo 93, inciso IX, da CF. Violação. Não ocorrência. Princípios do contraditório e da ampla defesa. Repercussão geral. Inexistência. 1. Não procede a alegada violação do art. 93, inciso IX, da Constituição Federal, haja vista que a jurisdição foi prestada, no caso, mediante decisões suficientemente motivadas, não obstante contrárias à pretensão da parte recorrente. 2. Ausência de repercussão geral do tema relativo à suposta violação dos princípios do contraditório, da ampla defesa, dos limites da coisa julgada e do devido processo legal (ARE $\mathrm{n}^{\circ}$ 748.371/MT, Relator o Ministro Gilmar Mendes, Dje de 1\%/8/13). 3. Agravo regimental não provido.

(ARE 943942 AgR, Relator(a): Min. DIAS TOFFOLI, Segunda Turma, julgado em 01/03/2016, PROCESSO ELETRÔNICO Dje-051 DIVULG 17-03-2016 PUBLIC 18-03-2016).

Mister a partir do estudo dos julgados, identificar o posicionamento dominante pela Corte do STF ao discorrer a respeito do artigo 93, IX, da Constituição Federal. É majoritário, conforme se pode perceber, o entendimento de que não possui o magistrado o dever de fundamentar todos os argumentos trazidos pela parte, tendo em vista que, até a entrada em vigor do novo CPC, não havia uma normatização constitucional e nem infraconstitucional que regulamentasse a maneira como uma decisão deveria ou não ser fundamentada. Fato que evidencia, ainda mais, a maneira solipsista de julgar, conferindo ao magistrado uma maior autoridade na relação processual.

Consoante ao exposto, Marcelo Andrade Cattoni de Oliveira argumenta que no Supremo Tribunal Federal, majoritariamente, em relação ao previsto no artigo 93, IX, da Constituição Federal, desenvolveu-se um entendimento no sentido de que o ato do magistrado não está sujeito a responder todas as alegações trazidas pelas partes contidas no processo, nem se pronunciar sobre todos os fundamentos trazidos por um provimento impugnado em sede de um juízo recursal (OLIVEIRA, 2016, p. 111).

Cattoni Oliveira ainda escreve que

Segundo o entendimento do Min. Gilmar Mendes, em que o texto constitucional faz referência a uma exigência de fundamentação, deve-se ler apenas a necessidade de uma motivação (mais uma vez, aqui, basta-se-ia que o magistrado colocasse na decisão o seu entendimento de forma solipsista, 
pois é o seu querer, como ato de autoridade - e não um possível consenso sobre a correção - que faria suficiente a exigência constitucional). (OLIVEIRA, 2016, p. 111).

Diante dos posicionamentos, em suma majoritários, apresentados pelo STF, observase que o ato de controle público da decisão, que deveria ser uma conseqüência do dever de fundamentação, acaba por tornar-se um ato solipsista do magistrado (OLIVEIRA, 2016, p. 111), o que resulta em um fortalecimento do princípio do livre convencimento, permitindo uma maior liberdade e subjetividade do julgador ao decidir. Tal situação reflete diretamente no contraditório, princípio que deveria ser entendido como uma oportunidade de manifestação de todas as partes envolvidas na relação processual, mas que é sabotado a partir do momento que o poder de decisão recai em apenas um sujeito do processo.

\section{CONCLUSÃO}

A fundamentação constitui preceito de ordem pública, verdadeira garantia processual prevista na Constituição, e tem o mérito de colocar a administração da justiça a salvo da suspeita de dois dos piores vícios que lhe podem macular: o arbítrio e a parcialidade. Nesse sentido, os entendimentos do STF aqui discutidos representam a pretensão de se supervalorizar uma determinada concepção do que sejam celeridade e efetividade do processo acabando por conduzir à uma autorização de quase total desconsideração do caso concreto sub judice, bem como de toda a densidade argumentativa que possa resultar da efetiva participação das parte.

Considerada a posição do STF no sistema jurídico brasileiro, bem como a tendência crescente de padronização de entendimentos a partir de decisões emanadas da referida Corte, torna-se ainda mais urgente a reflexão e a crítica no tocante à flexibilização de garantias processuais, notadamente do principio da fundamentação que conforme amplamente abordado afeta toda a estrutura do devido processo legal, assegurando ainda o controle social das decisões evitando que as mesmas assumam caráter político.

A legitimidade das decisões judiciais não decore simplesmente do modo como o juiz chegou a ser empossado ou ao tribunal no qual atua. O que legitima as decisões, no contexto de uma sociedade democrática e plural, são as garantias processuais atribuídas às partes. 


\section{REFERÊNCIAS BIBLIOGRAFICAS}

BRASIL. Constituição (1988). Constituição da República Federativa do Brasil. Brasília:

Senado, 1988a.

Disponível

em:

http://www.senado.gov.br/legislacao/const/con1988/CON1988_29.03.2012/index.shtm.

Acesso em: 21 de março de 2016.

BRASIL. Código de Processo Civil (2015). Brasília: Senado. Disponível em: http://www.planalto.gov.br/ccivil_03/_ato2015-2018/2015/lei/113105.htm. Acesso em: 21 de março de 2016.

BRASIL. Código de Processo Civil (1973). Brasília: Senado. Disponível em: http://www2.camara.leg.br/legin/fed/lei/1970-1979/lei-5869-11-janeiro-1973-357991-normapl.html. Acesso em: 21 de março de 2016.

BRASIL. Código de Processo Penal (1941). Brasília: Senado. Disponível em: http://www.planalto.gov.br/ccivil_03/Decreto-Lei/Del3689Compilado.htm. Acesso em: 21 de março de 2016.

BRASIL. Lei 9.099 (1995). Brasília: Senado. Disponível em: http://www.planalto.gov.br/ccivil_03/leis/L9099.htm. Acesso em: 21 de março de 2016.

BRASIL. Consolidação das Leis do Trabalho (1943). Brasília: Senado. Disponível em: http://www.planalto.gov.br/ccivil_03/decreto-lei/Del5452.htm. Acesso em: 21 de março de 2016.

BRASIL. Código de Processo Penal Militar (1969). Brasília: Senado. Disponível em: http://www.planalto.gov.br/ccivil_03/Decreto-Lei/Del1002.htm. Acesso em: 21 de março de 2016.

BRASIL. Supremo Tribunal Federal. AI 791292 QO-RG, Relator: Min. GILMAR MENDES, julgado em 23/06/2010, repercussão geral. DJe-149 12/08/2010. Disponível em: $<$ http://redir.stf.jus.br/paginadorpub/paginador.jsp?docTP=AC\&docID=613496>. Acesso em 19 de março 2016. 
BRASIL. Supremo Tribunal Federal. ARE 939246 AgR, Relator(a): Min. EDSON FACHIN, Primeira Turma, julgado em 01/03/2016, ACÓRDÃO ELETRÔNICO DJe-049 DIVULG 1503-2016 PUBLIC 16-03-2016. Disponível em: $<$ http://redir.stf.jus.br/paginadorpub/paginador.jsp?docTP=TP\&docID=10498511> . Acesso em 19 de março 2016.

BRASIL. Supremo Tribunal Federal. ARE 943942 AgR, Relator(a): Min. DIAS TOFFOLI, Segunda Turma, julgado em 01/03/2016, PROCESSO ELETRÔNICO DJe-051 DIVULG 1703-2016 PUBLIC 18-03-2016.

Disponível em:<http://redir.stf.jus.br/paginadorpub/paginador.jsp?docTP=TP\&docID=10523027>. Acesso em 19 de março 2016.

BARBOSA MOREIRA, Jose Carlos. A motivação das decisões judiciais como garantia inerente ao Estado de Direito in Temas de Direito Processual, 2 ed., São Paulo: Saraiva, 1988.

BRÊTAS, Ronaldo de Carvalho Dias. Processo Constitucional e Estado Democrático de Direito. Belo Horizonte: Del Rey, 2010.

GHEDINI NETO, Armando. Técnica estrutural dos atos jurisdicionais decisórios. In: BRÊTAS, Ronaldo de Carvalho Dias e SOARES, Carlos Henrique (Coords.). Técnica Processual. Belo Horizonte: Del Rey, 2015.

CARVALHO, Kildare Gonçalves. Direito Constitucional. 16 ed. Belo Horizonte: Del Rey, 2010 .

CINTRA, Antônio Carlos de Araujo, GRINOVER, Ada Pellegrini, DINAMARCO, Cândido Rangel. Teoria Geral do Processo. 20 ed. São Paulo: Malheiros, 2004.

FERRAJOLI, Luigi. Direito e Razão: teoria do garantismo penal. São Paulo: Revista dos Tribunais, 2002, p.497.

LEAL, André Cordeiro. Instrumentalidade do Processo em Crise. Belo Horizonte: Mandamentos, Faculdade de Ciências Humanas/FUMEC, 2008.

LEAL, André Cordeiro. O contraditório e a fundamentação das decisões no direito processual democrático. Belo Horizonte: Mandamentos, 2002. 
LEAL, Rosemiro Pereira. Teoria Geral do Processo: Primeiros estudos. 12 ed. rev. e atual. Rio de Janeiro: Forense, 2014.

MEDINA, Paulo Roberto de Gouvêa. Direito Processual Constitucional. 3 ed. Rio de Janeiro: Forense, 2006.

MENDES, Gilmar Ferreira. Direitos Fundamentais e Controle de Constitucionalidade: estudos de direito constitucional. São Paulo: Saraiva, 2004.

NOGUEIRA, José Maurício. Aspectos sobre o controle das decisões judiciais. In: MEDINA, José Miguel Garcia; CRUZ, Luana Pedrosa de Figueiredo; CERQUEIRA, Luís Otávio Sequeira de; GOMES JUNIOR, Luiz Manoel. Os poderes do juiz e o controle das decisões judiciais/coordenação José Miguel Garcia Medina et al. - São Paulo: Editora Revista dos Tribunais, 2008.

NEGRÃO, Theotonio. Código de Processo Civil e legislação processual em vigor. 32 ed., São Paulo: Saraiva, 2001.

OLIVEIRA, Marcelo Andrade Cattoni de. Processo Constitucional. 2 ed. Belo Horizonte: Pergamum, 2013.

OLIVEIRA, Marcelo Andrade Cattoni de. Processo constitucional. 3. ed. rev. e ampl. - Belo Horizonte: Fórum, 2016.

PIMENTA BUEnO, José Antônio. Direito Publico brasileiro e análise da Constituição do Império. Rio de Janeiro: Imprensa Nacional, 1958. 